\title{
Effect of Moisture Content and Wood Structure on the Amenability of Japanese Red Pine (Pinus densiflora S. et Z.) to Liquid Treatment*1
}

\author{
Sheikh Ali Ahmed*2, Song Ho Chong*3, Seung Hyun Hong*4, \\ $\mathrm{Ae} \mathrm{Ju} \mathrm{Kim}{ }^{* 4}$, and Su Kyoung Chun ${ }^{*+}$
}

\begin{abstract}
This paper explains the effects of wood drying on treatability (as determined by water uptake) of Japanese red pine (Pinus densiflora S. et Z.) at the sevenmoisture content (MC) levels above and below the fiber saturation point (FSP). According to the experimental results, it was found that water uptake (as the percentage of void volume filledwith distilled water, VVF\%) was influenced by level of moisture content and percentage of void volume filled was improved effectively by kiln drying process. A significant relationship between moisture content and treatability was established. Permeability and liquid uptake were decreased above the FSP due to the effect of the less void space available in wood. Even though increased liquid uptake was observed at lower moisture content, no significant differences was observed moisture content below $20 \%$. Therefore, this species need to be initially dried below FSP before treated with liquids. But drying moisture content below $10 \%$ might not be economical for the commercial purpose comparing drying the wood between 10 and $20 \%$ moisture content. The result of this study inferred that the treatability of pine wood can be improved by reducing the moisture content up to a certain level of $10 \sim 20 \%$ for allowing better performance.
\end{abstract}

Keywords : Japanese red pine, moisture content, wood drying, treatability, anatomical characteristics

\section{INTRODUCTION}

Wood is a porous material (Kollmann and Côté, 1984; Tsoumis, 1991) composed of cell wall substances and cavities containing air and ex- tractives (Dinwoodie, 1981). The density of the cell wall substances is ca. $1.53 \mathrm{~g} / \mathrm{cm}^{3}$ on oven-dry mass and volume basis and practically constant for all wood. Thus, the cell wall substances are one and half times heavier than water (Walker,

*1 Received on March 2, 2010; accepted on March 20, 2010

*2 Department of Forest Biomaterials Engineering, College of Forest and Environmental Sciences, Kangwon National University, Chuncheon, Kangwon 200-701, Korea

*3 Department of Forest Resources Utilization, Korea Forest Research Institute, Seoul 130-712, Korea

*4 Kangwon National University, Chuncheon, Kangwon 200-701, Korea

† Corresponding author : Su Kyoung Chun (e-mail: chun@kangwon.ac.kr) 
1993). A cubic meter of cell wall substances weigh roughly about $1500 \mathrm{~kg} / \mathrm{m}^{3}$ for all species but wood is surely not comprised of $100 \%$ cell wall substances as it contains air pockets in the cell lumen (Walker, 1993). The oven-dry density of any wood species is the direct reflection of the amount of space occupied by the wood tissue (Walker, 1993). The density of different timbers (based on oven-day mass and oven-dry volume) varies from about 0.04 for balsa (Ochroma lagopus $\mathrm{Sw}$.) to 1.4 for guayacan (Guajacum officinales L.) and snakewood (Brosimum aubletii Poepp. \& Endl.). This indicates that the void volume of the lightest wood is $97 \%$ and $7 \%$ for the heaviest wood (Kollmann and Côté, 1984). The permeability of wood varies considerably from species to species depending on the variation of void space available (Palin and Petty, 1981; Usta and Hale, 2004).

Wood is anisotropic in permeability (as in other properties) and a large difference exists between the longitudinal and lateral flow. Liquid flow in wood occurs primarily in the longitudinal direction. The ratio of longitudinal to lateral flow is about 30 to 1 (Stamm, 1973). However, lateral movement of fluid has greater importance when treating wood. Without lateral movement, timbers could not be adequately treated because of low retention and poor distribution of liquid in the wood. The flow and diffusion of fluids through wood follow different laws and vary in different structures. Voids in wood differ by the size of vessels in hardwoods and tracheids in softwood, which are visible under very low magnification. The fine pit structure controls the rate of flow of fluids (Bonner and Thomas, 1972; Murmanis and Chudnoff, 1979; Flynn, 1995). Furthermore, under the presence of high structural complexity and difference of types, geometry, and distribution of capillary, fluid permeability in wood varies considerably among different families, genera, and species (Malkov et al., 2003).

Besides the structural diversity, moisture content (MC) is one of the most important variables influencing the treatment of wood and hence wood has to be seasoned or to be dried (Hunt and Garret, 1967; Tsoumis, 1991). For instance, properly seasoned wood of all species is more easily penetrated by pressure process than unseasoned wood (Wilkinson, 1979). As Japanese red pine is one of the most important tree species in Korea (Lee et al., 2004), it is selected to find the MC level at which the treatability is acceptable. The aim of this paper was set to determine the effectiveness of full-cell liquid (distilled water) treatment of Japanese red pine at different moisture regime. Some anatomical characteristics regarding the liquid penetration in wood are also investigated and discussed.

\section{MATERIALS and METHODS}

Wood sample of 40-year-old Japanese red pine (Pinus densiflora S. et Z.) was collected from non-leaning and defect-free tree from Jimari, Sabukmeyon, Chunchon, Kagnwon do, Republic of Korea $\left(37^{\circ} 58^{\prime} \mathrm{N}, 127^{\circ} 35^{\prime} \mathrm{E}, 290 \mathrm{~m}\right.$ from sea level). Wood discs $(150 \mathrm{~mm})$ cut at $1.3 \mathrm{~m}$ above the ground level and were kept in an air tight bag immediately to prevent the moisture loss.

\subsection{Measurement of Liquid Uptake}

Fourteen sample stakes were cut in cross section of $20 \times 20 \mathrm{~mm}$ from sapwood and heartwood. Thereafter, each stake was cut into 4 sample blocks of $30 \mathrm{~mm}$ long and total 56 sample blocks were obtained (Fig. 1). Six batches of eight sample blocks (4 from sapwood and 4 from heartwood) were kiln dried with mild drying schedule and $\mathrm{MC}$ was adjusted to $70 \%$, 


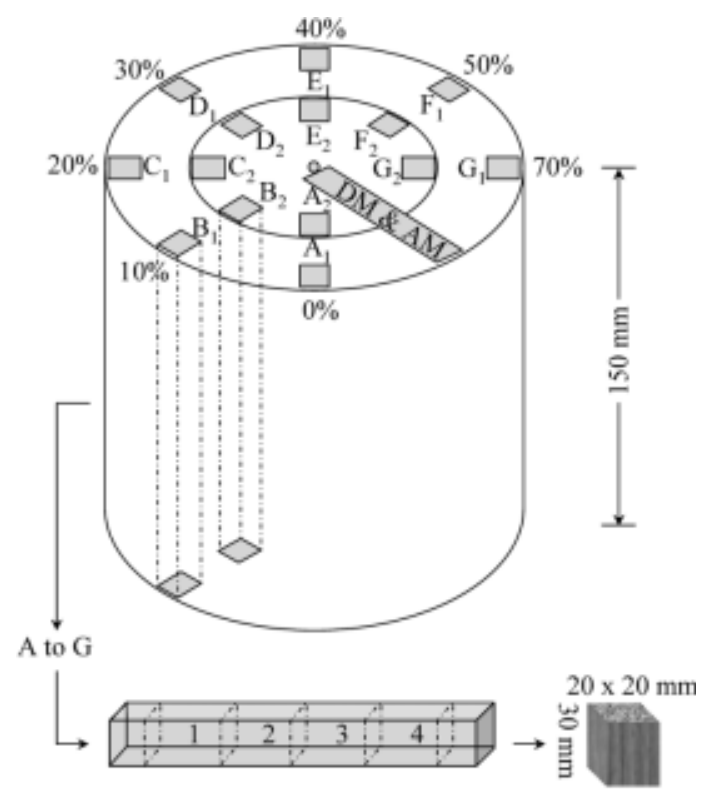

Fig. 1. Diagram showing preparation of sample blocks from wood disc. DM: Density measurement; AM: Anatomical measurement; $A_{1}-G_{1}$ : sapwood samples, $\mathrm{A}_{2}-\mathrm{G}_{2}$ : heartwood samples.

$50 \%, 40 \%, 30 \%, 20 \%$ and $10 \%$. The other batch of sample blocks was oven dried at 103 $\pm 2{ }^{\circ} \mathrm{C}$ for 48 hours to set the $\mathrm{MC}$ at $0 \%$. When target MC was achieved, sample blocks were then treated with distilled water. Treatment was accomplished using a conventional full-cell process of 15 minutes vacuum at $-82.7 \mathrm{kPa}$ followed by a pressure impregnation of $1,471 \mathrm{kPa}$ for 60 minutes. After treatment, the maximum possible liquid uptake was calculated as percentage of void volume filled by distilled water.

\subsection{Measurement of Wood Density}

Nine sample blocks of $20 \times 20 \times 30 \mathrm{~mm}$ collected from both sapwood and heartwood were used for estimation of oven-dry density based on oven-dry mass and volume as discussed in KSA (2001). Dimensions of sample block were measured in all principal directions with a mi- crometer to the nearest $0.01 \mathrm{~mm}$. Density $\left(\mathrm{D}_{\mathrm{MC}}\right)$ at each moisture content was calculated as follows: $\mathrm{D}_{0}\left[\{1+(\mathrm{MC} / 100)\} /\left\{1+\left(0.84 \times \mathrm{D}_{0}(\mathrm{MC} / 100)\right\}\right]\right.$ where, $\mathrm{D}_{0}=$ oven-dry density, $\mathrm{MC}=$ Percent moisture content (Kollmann and Côté, 1984). Permeability of liquid was calculated following the equation mentioned by Usta and Hale (2006).

$$
V V F \%=\frac{\left(\frac{M_{t}-M_{d}}{V}\right) \times 100}{P}
$$

Here, VVF is the percent void volume filled, $M_{t}$ is the mass of treated block $(\mathrm{g}) ; M_{d}$ is the mass of untreated block ( $\mathrm{g}), \mathrm{V}$ is the block volume $\left(\mathrm{cm}^{3}\right)$ and $\mathrm{P}$ is the porosity $(\%)$ as the fractional void volume of wood determined by $[\{1-($ density/1.53) $\} \times 100]$.

\subsection{Measurement of Wood Micro- structure}

Thin sections of $15 \sim 20 \mu \mathrm{m}$ thick from cross, radial, and tangential surfaces were obtained by using a sliding microtome. Permanent slides were prepared using Canada Balsam on glass slides after microtome sections were stained with safranine (Junsei Chemical Co., Ltd.) solution and dehydrated in series of alcohol. Lengths of longitudinal tracheid, ray parenchyma cell, and ray tracheid were measured from macerations by Schultze's solution. In this case, cell length was measured with image processing software (Image and Microscope Technology, $i$-solution 2.5) equipped with $i$-Camscope (model SV32). Each microstructural feature was measured from pith to bark.

For scanning electron microscopy, radial, tangential, and cross sectional blocks were finished with a microtome and the clean-cut surface was $(3 \mathrm{~mm} \times 3 \mathrm{~mm})$ made in $1 \mathrm{~mm}$ thickness. After vacuum-drying, blocks were adhered onto alu- 
Effect of Moisture Content and Wood Structure on the Amenability of Japanese Red Pine (Pinus densiflora S. et Z.) to Liquid Treatment

Table 1. Means and standard deviations of different anatomical features measured in red pine

\begin{tabular}{|c|c|c|c|c|c|c|c|c|c|}
\hline $\begin{array}{l}\text { Location in } \\
\text { growth ring }\end{array}$ & $\begin{array}{c}\text { Tracheid } \\
\text { tangential } \\
\text { diameter } \\
(\mu \mathrm{m})\end{array}$ & $\begin{array}{l}\text { Tracheid } \\
\text { radial } \\
\text { diameter } \\
(\mu \mathrm{m})\end{array}$ & $\begin{array}{l}\text { Tracheid } \\
\text { length } \\
(\mu \mathrm{m})\end{array}$ & $\begin{array}{c}\text { Cross } \\
\text { sectional } \\
\text { area of ray } \\
\text { parenchyma } \\
\left(\mu \mathrm{m}^{2}\right)\end{array}$ & $\begin{array}{l}\text { Ray } \\
\text { parenchyma } \\
\text { cell length } \\
\quad(\mu \mathrm{m})\end{array}$ & $\begin{array}{l}\text { Ray tracheid } \\
\text { length } \\
(\mu \mathrm{m})\end{array}$ & $\begin{array}{l}\text { Area of pit } \\
\text { aperture in } \\
\text { tracheid } \\
(\mu \mathrm{m})\end{array}$ & $\begin{array}{l}\text { Half-bordered } \\
\text { pit diameter } \\
(\mu \mathrm{m})\end{array}$ & $\begin{array}{l}\text { Margo } \\
\text { lattice size } \\
(\mathrm{nm})\end{array}$ \\
\hline Earlywood & $21.7 \pm 3.4$ & $38.8 \pm 6.9$ & $3295.6 \pm 1.1$ & $146.7 \pm 48.9$ & $152.8 \pm 67.4$ & $87.2 \pm 37.8$ & $24.6 \pm 6.8$ & $20.6 \pm 5.7$ & $354.7 \pm 145.5$ \\
\hline Latewood & $21.7 \pm 3.6$ & $21.6 \pm 3.7$ & $3362.6 \pm 1.0$ & $149.1 \pm 46.7$ & $155.8 \pm 63.1$ & $62.5 \pm 30.1$ & $11.2 \pm 4.9$ & $19.0 \pm 4.1$ & $328.8 \pm 90.3$ \\
\hline Average & 21.7 & 30.2 & 3329.1 & 147.9 & 154.3 & 74.8 & 17.9 & 19.8 & 341.8 \\
\hline
\end{tabular}

Tracheid : Longitudinal tracheid

minum stubs with a double-sided tape and coated with platinum $(\mathrm{Pt})$ by using an ion sputter apparatus (HITACHI E-1010). At different magnifications, the samples were then examined at accelerating voltage of $5 \mathrm{kV}$ in a Hitachi S-4300 FESEM (Field Emission Scanning Electron Microscope). All anatomical features were measured minimum 50 to maximum 1,110 times.

\subsection{Statistical Analysis}

Water permeability was analyzed by using one-way analysis of variance (ANOVA). When a significant difference was observed $(\mathrm{P} \leq 0.05)$, the ANOVA procedure was performed followed by a Duncan significant difference post hoc test to separate the moisture effect on water permeability (SPSS, Version 12.0.1, 2003).

\section{RESULTS and DISCUSSION}

\subsection{Anatomical Observation}

Different anatomical measurements for red pine are presented in Table 1. Ray parenchyma cell was found almost double in length when compared with ray tracheid. Half-bordered pit diameter in earlywood was found larger than that in latewood. The margo (Fig. 2F) consists of loose mesh of fibrils through which liquid can pass. The average margo lattice size was found 341.8

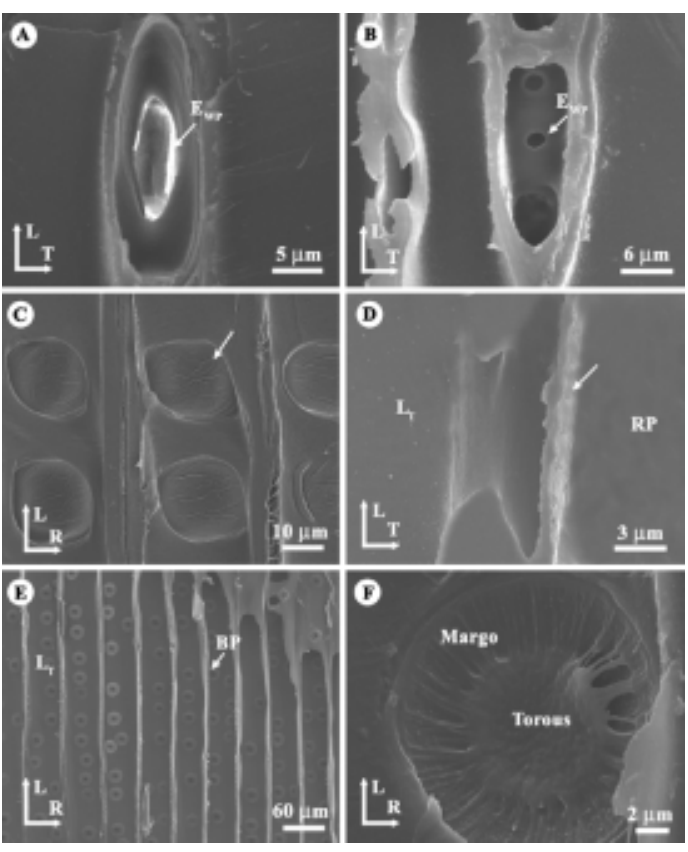

Fig. 2. Scanning electron micrograph of different pits in pine. A: End wall pit $\left(\mathrm{E}_{\mathrm{WP}}\right)$ in ray parenchyma cell. B: End wall pit in ray tracheid. $\mathrm{C}$ and D: Half-bordered pit, Arrow $=$ pit membrane, $\mathrm{L}_{\mathrm{T}}=$ longitudinal tracheid; $\mathrm{RP}=$ ray parenchyma. E: Longitudinal tracheid, $\mathrm{BP}=$ bordered pit. F: Bordered pit membrane.

$\mathrm{nm}$ by which it can be expected that tracheid conductivity would be higher than other cells due to the presence of highly porous margo in bordered pits. Different anatomical features presented in Table 1 are thought to control the 
Sheikh Ali Ahmed, Song Ho Chong, Seung Hyun Hong, Ae Ju Kim, and Su Kyoung Chun

Table 2. Comparison of wood density, porosity (void volume), and the percentage of void volume filled with distilled water at various moisture content

\begin{tabular}{|c|c|c|c|c|c|c|c|c|c|c|c|c|c|c|}
\hline \multirow{3}{*}{ Properties } & \multicolumn{14}{|c|}{ Moisture content level (\%) } \\
\hline & \multicolumn{2}{|c|}{0} & \multicolumn{2}{|c|}{10} & \multicolumn{2}{|c|}{20} & \multicolumn{2}{|c|}{30} & \multicolumn{2}{|c|}{40} & \multicolumn{2}{|c|}{50} & \multicolumn{2}{|c|}{70} \\
\hline & $\begin{array}{l}\mathrm{SW} \\
\left(\mathrm{A}_{1}\right) \\
\end{array}$ & $\begin{array}{l}\mathrm{HW} \\
\left(\mathrm{A}_{2}\right) \\
\end{array}$ & $\begin{array}{l}\mathrm{SW} \\
\left(\mathrm{B}_{1}\right) \\
\end{array}$ & $\begin{array}{l}\mathrm{HW} \\
\left(\mathrm{B}_{2}\right) \\
\end{array}$ & $\begin{array}{l}\mathrm{SW} \\
\left(\mathrm{C}_{1}\right) \\
\end{array}$ & $\begin{array}{l}\mathrm{HW} \\
\left(\mathrm{C}_{2}\right) \\
\end{array}$ & $\begin{array}{l}\mathrm{SW} \\
\left(\mathrm{D}_{1}\right) \\
\end{array}$ & $\begin{array}{l}\mathrm{HW} \\
\left(\mathrm{D}_{2}\right) \\
\end{array}$ & $\begin{array}{l}\mathrm{SW} \\
\left(\mathrm{E}_{1}\right) \\
\end{array}$ & $\begin{array}{l}\mathrm{HW} \\
\left(\mathrm{E}_{2}\right) \\
\end{array}$ & $\begin{array}{l}\mathrm{SW} \\
\left(\mathrm{F}_{1}\right) \\
\end{array}$ & $\begin{array}{l}\mathrm{HW} \\
\left(\mathrm{F}_{2}\right) \\
\end{array}$ & $\begin{array}{l}\mathrm{SW} \\
\left(\mathrm{G}_{1}\right) \\
\end{array}$ & $\begin{array}{l}\mathrm{HW} \\
\left(\mathrm{G}_{2}\right) \\
\end{array}$ \\
\hline $\mathrm{D}_{\mathrm{MC}}$ & 0.41 & 0.42 & 0.45 & 0.46 & 0.52 & 0.53 & 0.53 & 0.55 & 0.57 & 0.59 & 0.61 & 0.63 & 0.69 & 0.71 \\
\hline Porosity & 73.35 & 72.57 & 70.68 & 69.82 & 66.11 & 65.21 & 65.35 & 64.34 & 62.69 & 61.60 & 60.02 & 58.85 & 54.69 & 53.37 \\
\hline VVF & $87.34 a$ & $62 \mathrm{ab}$ & $54 a$ & $79.33 a$ & $7.38 \mathrm{~b}$ & 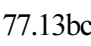 & .52 & 3.70 & 7.01 & 61.13 & 55.74 & 0.48 & 9.5 & $56.73 \mathrm{~g}$ \\
\hline
\end{tabular}

$\mathrm{SW}=$ sapwood; $\mathrm{HW}=$ heartwood

$A_{1}-G_{1}$ and $A_{2}-G_{2}$ are the samples from sapwood and heartwood at different MC regime, respectively

$\mathrm{D}_{\mathrm{MC}}\left(\mathrm{g} / \mathrm{cm}^{3}\right)$ is wood density by moisture content

Porosity (\%) is the fractional void volume of wood

VVF (\%) is percentage of void volume filled with water. Values are means of 4 replications in each MC regime.

Means with common letterin a given row are not significantly different at $\mathrm{P}<0.05$ level (DuncanMultiple Range Test, DMRT)

treatability of pine wood. The permeability of liquid in wood cells depends on the capillary structure; for example, if the cell is narrow and long with wider pit, it would conduct liquid at higher rate than those cells of oppsite properties (Ahmed and Chun, 2009).

The ray parenchyma cell has only one simple end wall (tangential wall) pit and ray tracheids have several bordered end wall pits (Fig. 2 A\&B). As a result, ray tracheids are expected to face much more obstacle in liquid flow than ray parenchyma. In this regard, Olsson et al. (2001) and Ahmed (2010) stated that ray parenchyma cell in pine was found higher permeable than ray tracheid. We also argue that the relative importance of the ray parenchyma cell as providing a transverse flow path is of greater importance than ray tracheid. The half bordered pits (Fig. 2C\&D) in pine providing lateral flow paths has been proposed by other researchers (Trenard and Gueneau, 1984), who suggested that the dividing membrane is damaged at some critical level of pressure. In this experiment, the applied pressure gradient was high enough $(1,471 \mathrm{kPa})$ to damage the thin membrane of half bordered pit to serve as important flow paths.

\subsection{Liquid Permeability}

As shown in Table 2, a significant relationship was found between increasing percentage of void volume filled with distilled water and decreasing wood density due to the decrease of MC (from $70 \%$ to $0 \%$ ). Table 2 summarizes also that below FSP, the permeability of water still increases in greater extent. However, drying to very low MC did not significantly improve the permeability within the range of $0 \sim 20 \%$ MC. Thus, drying the wood to below $10 \% \mathrm{MC}$ would not be more economical for any commercial purpose than that up to $10 \sim 20 \% \mathrm{MC}$.

From the outcome of above findings, it was clear that there was a negative relationship between MC and permeability of distilled water $\left(\mathrm{R}^{2}=0.9389\right)$. Permeability increased with the decrease of $\mathrm{MC}$ and the relation could be expressed by the linear regression (Fig. 3). A similar trend was also reported by Hassler et al. (1998), Usta (2006), and Islam et al. (2009) who summarized that the lower MC resulted in improved treatability. For instance, Skaar (1972) 
Effect of Moisture Content and Wood Structure on the Amenability of Japanese Red Pine (Pinus densiflora S. et Z.) to Liquid Treatment

Table 3. Mean and standard deviation of water uptake at various moisture content

\begin{tabular}{|c|c|c|c|c|c|c|c|c|c|c|c|c|c|c|}
\hline & \multicolumn{14}{|c|}{ Moisture content level (\%) } \\
\hline & \multicolumn{2}{|c|}{0} & \multicolumn{2}{|c|}{10} & \multicolumn{2}{|c|}{20} & \multicolumn{2}{|c|}{30} & \multicolumn{2}{|c|}{40} & \multicolumn{2}{|c|}{50} & \multicolumn{2}{|c|}{70} \\
\hline & $\begin{array}{l}\mathrm{SW} \\
\left(\mathrm{A}_{1}\right)\end{array}$ & $\begin{array}{l}\mathrm{HW} \\
\left(\mathrm{A}_{2}\right) \\
\end{array}$ & $\begin{array}{l}\mathrm{SW} \\
\left(\mathrm{B}_{1}\right)\end{array}$ & $\begin{array}{l}\mathrm{HW} \\
\left(\mathrm{B}_{2}\right)\end{array}$ & $\begin{array}{l}\mathrm{SW} \\
\left(\mathrm{C}_{1}\right)\end{array}$ & $\begin{array}{l}\mathrm{HW} \\
\left(\mathrm{C}_{2}\right)\end{array}$ & $\begin{array}{l}\mathrm{SW} \\
\left(\mathrm{D}_{1}\right)\end{array}$ & $\begin{array}{l}\mathrm{HW} \\
\left(\mathrm{D}_{2}\right)\end{array}$ & $\begin{array}{l}\text { SW } \\
\left(E_{1}\right)\end{array}$ & $\begin{array}{l}\mathrm{HW} \\
\left(\mathrm{E}_{2}\right) \\
\end{array}$ & $\begin{array}{l}\mathrm{SW} \\
\left(\mathrm{F}_{1}\right)\end{array}$ & $\begin{array}{l}\mathrm{HW} \\
\left(\mathrm{F}_{2}\right)\end{array}$ & $\begin{array}{l}\mathrm{SW} \\
\left(\mathrm{G}_{1}\right)\end{array}$ & $\begin{array}{l}\mathrm{HW} \\
\left(\mathrm{G}_{2}\right)\end{array}$ \\
\hline \multirow{3}{*}{$\begin{array}{c}\text { Water uptake } \\
\qquad\left(\mathrm{g} / \mathrm{cm}^{3}\right)\end{array}$} & 0.643 & 0.583 & 0.578 & 0.553 & 0.503 & 0.503 & 0.468 & 0.440 & 0.420 & 0.377 & 0.390 & 0.353 & 0.313 & 0.303 \\
\hline & \pm & \pm & \pm & \pm & \pm & \pm & \pm & \pm & \pm & \pm & \pm & \pm & \pm & \pm \\
\hline & 0.04 & 0.01 & 0.02 & 0.06 & 0.02 & 0.02 & 0.01 & 0.03 & 0.03 & 0.11 & 0.02 & 0.01 & 0.01 & 0.01 \\
\hline
\end{tabular}

$\mathrm{SW}=$ sapwood; $\mathrm{HW}=$ heartwood

$\mathrm{A}_{1} \sim \mathrm{G}_{1}$ and $\mathrm{A}_{2} \sim \mathrm{G}_{2}$ are the samples from sapwood and heartwood at different MC regime, respectively

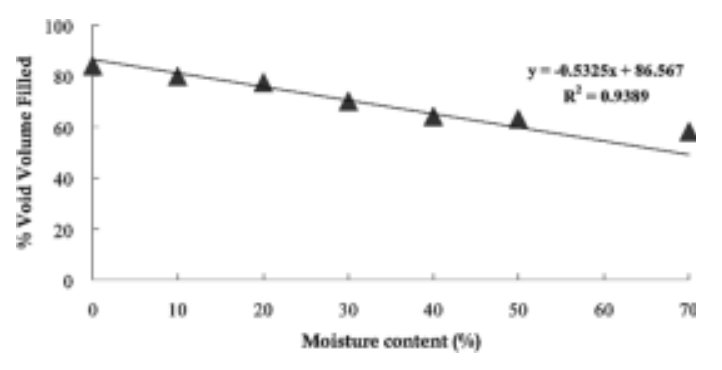

Fig. 3. Relationship between water permeability and moisture content of wood. Each point reflects the mean of 8 replications.

stated that the existing amount of moisture in wood affected the amount of space (void volume) available for the fluid uptake by reducing the porosity. Permeability could be enhanced by drying process. In this respect, the result obtained in this experiment appears to fit the previous findings.

Wood is a material with high variation in terms of structure and properties because of the existence of sapwood, heartwood, earlywood, and latewood, etc. Though wood is cut from the same tree, the density variation exists among species. Table 3 shows that the water uptake increases with decrease of MC. At different MC regime, the uptake of sapwood was found higher than that of heartwood. The transformation from sapwood to heartwood causes changes in the parenchyma cells because of polyphenols laid down in the window-like cross-field pits (half-bordered pits) and in the walls of ray pa- renchyma cells (Bauch et al., 1974; Bamber and Fukazawa, 1985). We believe that this may restrict transverse flow from longitudinal tracheids passing through the large cross-field pits in ray parenchyma of pine. Longitudinal permeability mainly occurs through tracheids which interconnected through bordered pits. When the bordered pit is fully unaspirated, it is claimed to offer an important flow path for liquids. Otherwise, it is a vital obstacle when it is aspirated (Olsson et al., 2001). The lower permeability of pine heartwood is often claimed to be attributed to a high degree of aspiration of the bordered pits (Erickson, 1970). In case of green wood, most of the pit tori are unaspirated in the sapwood but aspirated in heartwood (Bao et al., 2001). In this experiment it was found that about $13.16 \%$ of pits in sapwood and $91.96 \%$ of pits in heartwood were aspirated at green state. On the other hand, $87.59 \%$ of pits in sapwood and $94.44 \%$ of pits in heartwood were aspirated at air dry state. Besides, occlusion and incrustations of the bordered pit membranes could add to the resistance to flow (Olsson et al., 2001). Hence, this may be another mechanism responsible for the reduced permeability of pine heartwood. To enhance the permeability in both sapwood and heartwood, a pressure gradient was applied because high pressure could cause the stretching and bulging of the pit membranes due to plasticity of wood, thus making the pit membrane openings larger (Paranyi and 
Rabinovitch, 1955). The higher pressure was applied, the more solubility of air into liquid was achieved. Therefore, a higher degree of penetration was reached.

According to the overall result of this investigation, it was clear that the drying process significantly improved the percentage of void volume filled with water because porosity was related to wood density at different MC. When the wood had higher MC, it was difficult to treat since only limited space was available to penetrate. The maximum volume of liquid which could be absorbed by wood would be achieved by reducing the MC. If other liquids like preservative solutions were used instead of distilled water, the percentage of void volume filled with water would differ from this experimental result, because the permeability of wood could be influenced by different factors of liquid likemolecular mass, surface tension, viscosity, the affinity between the solution and wood (Smith et al., 1996; Scheikl and Dunky, 1998; Furuno et al., 2004). Surface tension of liquid is considered one of the important factors affecting the liquid flow (Collett, 1972). The surface tension acts along the surface and tends to minimize its area. If the surface tension decreases, the ability of the liquid to wet the surrounding wood cell will become greater.

\section{CONCLUSIONS}

The main purpose of this study was to demonstrate the reliable experimental findings that would be subjected for the full-cell liquid treatment process of Japanese red pine which is the one of the most important softwood species. As seasoning and treating properties of this species are similar to those of other softwood species, all the results derived in present study might be more important for the further treatment or finishing processes of wood for use as struc- tural/non-structural and indoor/outdoor purposes. The treatability of wood can increase with decreasing MC. The experimental observation indicated that water permeability (as the percentage of void volume filled with distilled water) increased in greater extent with the decrease of MC below the FSP but drying to very low MC appeared not to improve treatability significantly, especially below $20 \%$ MC. It is suggested that reducing the $\mathrm{MC}$ of pine wood up to $10 \sim 20 \%$ was desirable for getting higher permeability.

\section{ACKNOWLEDGEMENT}

This work was supported by the Korea Research Foundation Grant funded by the Korean Government (MEST) (KRF-2009-361-G00013) and Kangwon National University.

\section{REFERENCES}

1. Ahmed, S. A. and S. K. Chun. 2009. Observation of liquid permeability related to anatomical characteristics in Samanea saman. Turkish Journal of Agriculture and Forestry 33(2): 155 163.

2. Ahmed, S. A. 2010. The effects of woodchip fertilizer on rice and tree seedlings. Ph.D. Thesis, Kangwon National University, Republic of Korea.

3. Bamber, R. K. and K. Fukazawa. 1985. Sapwood and heartwood: A review. Forestry Abstract 46(9): $567 \sim 580$.

4. Bao, F., J. Lu, and Y. Zhao. 2001. Effect of bordered pit torus position on the permeability of Chinese Yezo spruce. Wood and Fiber Science 33(2): $193 \sim 199$.

5. Bauch, J., W. Schweers, and H. Berndt. 1974. Lignification during heartwood formation: Comparative study of rays and bordered pit membranes in coniferous woods. Holzforschung 28(3): $86 \sim 91$.

6. Bonner, L. D. and R. J. Thomas. 1972. The ultrastructure of intercellular passageways in vessels of yellow poplar (Liriodendron tulipifera L.). Part I: Vessel pitting. Wood Science and Tech- 
nology 6(3): $196 \sim 203$.

7. Collett, B. M. 1972. A review of surface and interracial adhesion in wood science and related fields. Wood Science and Technology 6(1): $1 \sim 42$.

8. Dinwoodie, J. M. 1981. Timber: Its structure, properties and utilisation. 6th edition, Macmillan, London.

9. Erickson, H. D. 1970. Permeability of southern pine wood - A review. Wood Science 2(3): 149 $\sim 158$.

10. Flynn, K. A. 1995. A review of the permeability, fluid flow, and anatomy of spruce (Picea spp.). Wood and Fiber Science 27(3): 278 284.

11. Furuno, T., T. Imamamura, and H. Kajita. 2004. The modification of wood by treatment with low molecular weight phenol-formaldehyde resin: A properties enhancement with neutralized phenolic-resin and resin penetration into wood cell wall. Wood Science and Technology 37(5): 349 $\sim 361$.

12. Hassler, C. C., J. J. Slahor, R. C. DeGroot, and D. J. Gardner. 1998. Preservative treatment evaluation of five Appalachian hardwoods at two moisture contents. Forest Product Journal 48(7/8): 37 $\sim 42$.

13. Hunt, G. M. and G. A. Garrett. 1967. Wood preservation. McGraw-Hill, New York.

14. Islam, M. N., K. Ando, H. Yamauchi, and N. Hattori. 2009. Effects of species and moisture content on penetration of liquid in laser incised lumber by the passive impregnation method. European Journal of Wood and Wood Products 67(2): $129 \sim 133$.

15. Kollmann, F. F. P. and W. A. Côté. 1984. Principles of wood science and technology: I. Solid wood. Springer-Verlag, Berlin.

16. KSA (Korea Standard Association) 2001. Determination of density and specific gravity of wood. KS F 2198.

17. Lee, W. K., K. von Gadow, D. J. Chung, J. L. Lee, and M. Y. Shin. 2004. DBH growth model for Pinus densiflora and Quercus variabilis mixed forests in central Korea. Ecological Modelling 176(1-2): $187 \sim 200$.

18. Malkov, S., P. Tikka, and J. Gullichsen. 2003. Towards the complete impregnation of wood chips with aqueous solutions: Part I. A retro- spective and critical evaluation of the penetration process. Paperi ja Puu 85(8): $460 \sim 466$.

19. Murmanis, L. and M. Chudnoff. 1979. Lateral flow in beech and birch as revealed by the electron microscope. Wood Science and Technology 13(2): $79 \sim 87$.

20. Olsson, T., M. Megnis, J. Varna, and H. Lindberg. 2001. Study of the transverse liquid flow paths in pine and spruce using scanning electron microscopy. Journal of Wood Science 47(4): 282 288 .

21. Palin, M. A. and J. A. Petty. 1981. Permeability of water of the cell wall materials of spruce heartwood. Wood Science and Technology 15(3): $161 \sim 169$.

22. Paranyi, N. I. and W. Rabinovitch. 1955. Determination of penetration rate of liquid media into wood using a quartz spiral balance. Pulp and Paper Magazine of Canada 56(3): 1164 1170.

23. Scheikl, M. and M. Dunky. 1998. Measurement of dynamic and static contact angles on wood for the determination of its surface tension and penetration of liquids into the wood surface. Holzforschung 52(1): 89 94.

24. Skaar, C. 1972. Water in wood. Syracuse University Press, New York.

25. Smith, W. B., N. Abdullah, D. Herdman, and R. C. DeGroot. 1996. Preservative treatment of red maple. Forest Product Journal 46(3): 35 41.

26. Stamm, A. J. 1973. Penetration of hardwoods by liquids. Wood Science and Technology 7(4): 285 296.

27. Trenard, Y. and P. Gueneau. 1984. Penetration pathways of liquid gallium in wood seen by scanning electron microscopy. Wood and Fiber Science 16(3): 403 410.

28. Tsoumis, G. T. 1991. Science and technology of wood: Structures, properties, utilization. Van Nostrand Reinhold, New York. p. 494.

29. Usta, I. and M. D. Hale. 2004. Effects of seed origin and site on the amenability of Sitka spruce (Picea sitchensis (Bong.) Carr.) grown in Britain to preservative treatment in longitudinal and radial directions. Forestry 77(1): 45 59.

30. Usta, I. 2006. Amenability of European silver fir (Abies alba Mill.) to preservative treatment by the full-cell process in longitudinal, tangential, radial and triplex flow pathways on the base of 
Sheikh Ali Ahmed, Song Ho Chong, Seung Hyun Hong, Ae Ju Kim, and Su Kyoung Chun

wood drying. Building and Environment 41(8): $1027 \sim 1033$.

31. Walker, J. F. C. 1993. Primary wood processing: Principles and practice. Chapman and Hall Ltd.,
London. p. 595.

32. Wilkinson, J. G. 1979. Industrial timber preservation. Associated Business Press, London. 